\title{
A history of hybrids? Genomic patterns of introgression in the True Geese
}

Jente Ottenburghs $^{1 *}$ D, Hendrik-Jan Megens ${ }^{2}$, Robert H. S. Kraus ${ }^{3,4}$, Pim van Hooft ${ }^{1}$, Sipke E. van Wieren ${ }^{1}$, Richard P. M. A. Crooijmans ${ }^{2}$, Ronald C. Ydenberg ${ }^{1,5}$, Martien A. M. Groenen ${ }^{2}$ and Herbert H. T. Prins ${ }^{1}$

\begin{abstract}
Background: The impacts of hybridization on the process of speciation are manifold, leading to distinct patterns across the genome. Genetic differentiation accumulates in certain genomic regions, while divergence is hampered in other regions by homogenizing gene flow, resulting in a heterogeneous genomic landscape. A consequence of this heterogeneity is that genomes are mosaics of different gene histories that can be compared to unravel complex speciation and hybridization events. However, incomplete lineage sorting (often the outcome of rapid speciation) can result in similar patterns. New statistical techniques, such as the D-statistic and hybridization networks, can be applied to disentangle the contributions of hybridization and incomplete lineage sorting. We unravel patterns of hybridization and incomplete lineage sorting during and after the diversification of the True Geese (family Anatidae, tribe Anserini, genera Anser and Branta) using an exon-based hybridization network approach and taking advantage of discordant gene tree histories by re-sequencing all taxa of this clade. In addition, we determine the timing of introgression and reconstruct historical effective population sizes for all goose species to infer which demographic or biogeographic factors might explain the observed patterns of introgression.

Results: We find indications for ancient interspecific gene flow during the diversification of the True Geese and were able to pinpoint several putative hybridization events. Specifically, in the genus Branta, both the ancestor of the White-cheeked Geese (Hawaiian Goose, Canada Goose, Cackling Goose and Barnacle Goose) and the ancestor of the Brent Goose hybridized with Red-breasted Goose. One hybridization network suggests a hybrid origin for the Red-breasted Goose, but this scenario seems unlikely and it not supported by the D-statistic analysis. The complex, highly reticulated evolutionary history of the genus Anser hampered the estimation of ancient hybridization events by means of hybridization networks. The reconstruction of historical effective population sizes shows that most species showed a steady increase during the Pliocene and Pleistocene. These large effective population sizes might have facilitated contact between diverging goose species, resulting in the establishment of hybrid zones and consequent gene flow.

Conclusions: Our analyses suggest that the evolutionary history of the True Geese is influenced by introgressive hybridization. The approach that we have used, based on genome-wide phylogenetic incongruence and network analyses, will be a useful procedure to reconstruct the complex evolutionary histories of many naturally hybridizing species groups.
\end{abstract}

Keywords: Hybridization, Phylogenetic Networks, D-statistic, PSMC, Phylogenomics

\footnotetext{
* Correspondence: jente.ottenburghs@hotmail.com

${ }^{1}$ Resource Ecology Group, Wageningen University \& Research,

Droevendaalsesteeg 3a, 6708 PB Wageningen, the Netherlands

Full list of author information is available at the end of the article
}

(c) The Author(s). 2017 Open Access This article is distributed under the terms of the Creative Commons Attribution 4.0 International License (http://creativecommons.org/licenses/by/4.0/), which permits unrestricted use, distribution, and reproduction in any medium, provided you give appropriate credit to the original author(s) and the source, provide a link to the Creative Commons license, and indicate if changes were made. The Creative Commons Public Domain Dedication waiver (http://creativecommons.org/publicdomain/zero/1.0/) applies to the data made available in this article, unless otherwise stated. 


\section{Background}

The impacts of hybridization on the process of speciation are manifold [1]. Hybridization may slow down or even reverse species divergence. It may also accelerate speciation via adaptive introgression or contribute to species diversity through the formation of new hybrid taxa. These diverse effects occur at different spatial scales and during different stages across the speciation continuum [2]. The consequences of hybridization and its role in impeding or promoting speciation are thus expected to vary widely among hybridizing taxa and at different stages of divergence. In every case, the pattern of hybridization is only a single snapshot of a complex and continuously changing interaction.

Genomics has become a standard practise, also in ornithology [3, 4], opening avenues to answer longstanding questions in speciation and hybridization [2, 5]. Studies in speciation and hybridization genomics revealed that levels of genetic differentiation between species can be highly variable across the genome: genetic differentiation accumulates in certain genomic regions, while divergence is hampered in other regions by homogenizing gene flow, resulting in a heterogeneous genomic landscape [6-8]. A consequence of this heterogeneity is that genomes are mosaics of different gene histories [9-11] that can be compared to unravel complex speciation and hybridization events [12, 13].

Complex evolutionary histories with rapid speciation (leading to incomplete lineage sorting) and hybridization mostly result in high levels of phylogenetic incongruence (i.e. gene tree discordance), which can be difficult to capture in a traditional, bifurcating phylogenetic tree. Phylogenetic networks can be a powerful tool to display and analyse these evolutionary histories [14, 15]. For example, Suh et al. [16] quantified the amount of incomplete lineage sorting along the Neoaves phylogeny [17] using presence/absence data for 2118 retrotransposons and concluded that the "complex demographic history [of the Neoaves] is more accurately represented as local networks within a species tree."

Here, we study patterns of hybridization and incomplete lineage sorting during and after the diversification of the True Geese (Table 1), a group of naturally hybridizing bird species $[18,19]$. The True Geese are classified in the waterfowl tribe Anserini and have been traditionally divided over two genera: Anser and Branta [20]. Hybrids have been reported within each genus [21-27], but also intergeneric hybrids have been documented [28-31]. Previous studies suggested that the evolutionary history of the True Geese is heavily influenced by hybridization and rapid diversification [12, 32]. In this study, we explore this suggestion using a network approach and taking advantage of phylogenetic incongruence across the whole genome by fully re-sequencing all species of the True Geese clade. Moreover, we attempt to quantify the relative contributions of gene flow and incomplete lineage sorting during the evolution of this bird group.

The contrasting evolutionary histories of these closely related genera also provide an excellent opportunity to study the effects of hybridization on the speciation process. The Anser-clade can be regarded as an adaptive radiation and was probably affected more by hybridization compared to the more gradually diversifying Branta-clade [12]. Therefore, we hypothesize that the phylogenetic network of Anser will be more complex (i.e. contain more interconnections between the taxa) compared to the Branta-network. Moreover, statistics quantifying interspecific gene flow, such as the D-statistic [33], are expected to be higher for Anser compared to Branta.

\section{Methods}

\section{Genomic dataset}

We collected blood samples from 19 goose (sub)species (Additional file 1: Table S1). From these blood samples, genomic DNA was isolated using the Qiagen Gentra kit (Qiagen Inc.). DNA quantity and quality were assessed using Qbit (Invitrogen, Life Technologies). Sequence libraries were made following Illumina protocols and sequenced paired-end (100 bp) on the HiSeq2500 (Illumina Inc.).

Paired-end reads were mapped to the Mallard (Anas platyrhynchos) genome, version 73 [34] using SMALT (http://www.sanger.ac.uk/science/tools/smalt-0). Over 99\% of the reads mapped successfully in all samples, but to decrease the incidence of off-site mapping only properly mapped reads were accepted, leading to mapping rates between $63 \%$ and $78 \%$ (Additional file 2: Table S2). Next, duplicate sequences were removed using SAMtools-dedup [35] and realigned with IndelRealigner in GATK 2.6 [36]. Variant sites calling was performed using UnifiedGenotyper in GATK 2.6 [36] with a heterozygosity value of 0.01 and a minimum base quality of 20 . Heterozygous sites were coded following the IUPAC nucleotide codes (e.g., R for A and G). The genomic positions for exons that were one-to-one orthologous between Mallard and other bird species (chicken, turkey, flycatcher and zebra finch) were retrieved from the ENSEMBL database.

From whole genome sequence data, we thus filtered out high quality exonic sequences. The final dataset is comprised of 41,736 unique exons, representing 5887 genes. The total alignment $(6,630,626 \mathrm{bp})$ was used in the neighbour-joining network and D-statistics analyses described below. In addition, we selected 3570 one-toone orthologous genes with a minimum length of $500 \mathrm{bp}$. These genes were analysed separately under a GTR $+\Gamma$ substitution model with 100 rapid bootstraps in RAxML 8.3 [37, 38]. The resulting gene trees were filtered on average bootstrap support (minimum $>50$ ). 
This final set of 3558 well-supported gene trees was used in the analysis to construct hybridization networks which calculate evolutionary trees taking into account hybridization - and to determine the timing of gene flow. Ottenburghs et al. [19] provide the phylogenetic framework for the current study, which focuses on introgressive hybridization during the evolutionary history of the True Geese.

\section{Gene flow analysis}

The D-statistic is a statistical test that was first employed to quantify the amount of genetic exchange between Neanderthals and humans [39]. It exploits the asymmetry in frequencies of two nonconcordant gene trees in a three-population setting [33]. Consider three populations (P1, P2 and P3) and an outgroup (O), of which P1 and $\mathrm{P} 2$ are sister clades. In this ordered set op populations [P1, P2, P3, O], two allelic patterns are of interest: "ABBA" and "BABA". The pattern ABBA refers to the situation in which P1 has the outgroup allele " $\mathrm{A}$ " and P2 and P3 share the derived allele " $\mathrm{B}$ ", while the pattern BABA refers to the situation in which $\mathrm{P} 2$ has the outgroup allele "A" and P1 and P3 share the derived allele "B". Under the null hypothesis that P1 and P2 are more closely related to each other than to P3, and if the ancestral populations of $\mathrm{P} 1, \mathrm{P} 2, \mathrm{P} 3$ were panmictic, then it is expected that the derived alleles in P3 match the derived alleles in P1 and P2 equally often [40, 41]. In other words, the patterns $\mathrm{ABBA}$ and BABA should occur in equal frequencies and the $\mathrm{D}$-statistic should equal zero:

$$
D\left(P_{1}, P_{2}, P_{3}, O\right)=\frac{\sum_{i=1}^{n} C_{A B B A}(i)-C_{B A B A}(i)}{\sum_{i=1}^{n} C_{A B B A}(i)+C_{B A B A}(i)}
$$

A D-statistic equal to zero is expected under incomplete lineage sorting. Gene flow between P1 and P3 (indicated by an overrepresentation of BABA) or P2 and P3 (indicated by an overrepresentation of ABBA) result in a D-statistic that is significantly different from zero. For both genera, D-statistics were calculated for all possible combinations of three species in the program HybridCheck version 1.0.1 [42]. We combined all species of the other genus as the outgroup. To test for significance, we performed jackknife resampling using blocks of $50,000 \mathrm{bp}$. We did not quantify asymmetric gene flow between genera due to the lack of a proper outgroup.

To infer the timing of gene flow (during or after the diversification), we dated 3558 gene trees using the software PATHd8 version 1.0 [43], setting the divergence time between the genera at 9.5 million years ago (based on previous estimates, [44, 45]). For every species pair, histograms were constructed from the resulting divergence times [46]. The patterns expected under incomplete lineage sorting and when gene flow occurred during or after the diversification are presented in Fig. 1.

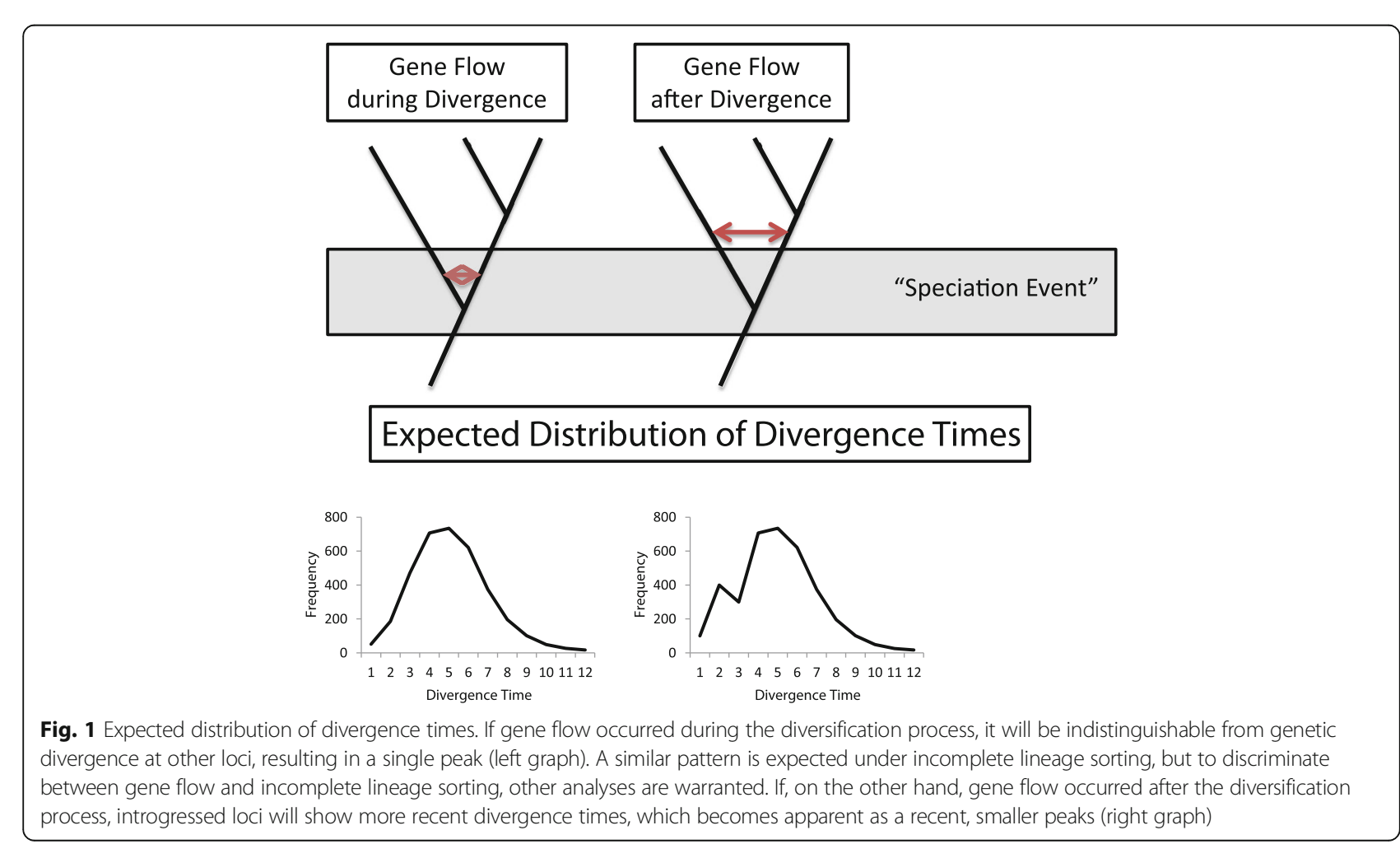


Table 1 Current taxonomy for the True Geese (tribe Anserini), previously published in Ottenburghs et al. (2016)

\begin{tabular}{|c|c|c|}
\hline English Name & Scientific Name & Subspecies \\
\hline \multicolumn{3}{|l|}{ Genus ANSER } \\
\hline Swan Goose & Anser cygnoides & \\
\hline Taiga Bean Goose & Anser fabalis & $\begin{array}{l}\text { A. f. fabalis } \\
\text { A. f. johanseni } \\
\text { A. f. middendorffii }\end{array}$ \\
\hline Tundra Bean Goose & Anser serrirostris & $\begin{array}{l}\text { A. s. rossicus } \\
\text { A. s. serrirostris }\end{array}$ \\
\hline Pink-footed Goose & Anser brachyrhynchus & \\
\hline Greater White-fronted Goose & Anser albifrons & $\begin{array}{l}\text { A. a. albifrons (Eurasian) } \\
\text { A. a. flavirostris (Greenland) } \\
\text { A. a. gambeli (Western) } \\
\text { A. a. frontalis (Western) } \\
\text { A. a. elgasi (Tule) }\end{array}$ \\
\hline Lesser White-fronted Goose & Anser erythropus & \\
\hline Greylag Goose & Anser anser & $\begin{array}{l}\text { A. a. anser (European) } \\
\text { A. a. rubrirostris (Siberian) }\end{array}$ \\
\hline Bar-headed Goose & Anser indicus & \\
\hline Emperor Goose & Anser canagicus & \\
\hline Snow Goose & Anser caerulescens & $\begin{array}{l}\text { A. c. caerulescens } \\
\text { A. c. atlantica }\end{array}$ \\
\hline Ross' Goose & Anser rossii & \\
\hline \multicolumn{3}{|l|}{ Genus BRANTA } \\
\hline Brent Goose & Branta bernicla & $\begin{array}{l}\text { B. b. bernicla (Dark-bellied) } \\
\text { B. b. hrota (Pale-bellied or Atlantic) } \\
\text { B. b. nigricans (Black) } \\
\text { B. b. orientalis }\end{array}$ \\
\hline Barnacle Goose & Branta leucopsis & \\
\hline Cackling Goose & Branta hutchinsii & $\begin{array}{l}\text { B. h. leucopareia (Aleutian) } \\
\text { B. h. hutchinsii (Richardson's) } \\
\text { B. h. minima (Minima) } \\
\text { B. h. taverneri (Taverner's) }\end{array}$ \\
\hline Canada Goose & Branta canadensis & $\begin{array}{l}\text { B. c. moffitti } \\
\text { B. c. maxima } \\
\text { B. c. occidentalis } \\
\text { B. c. fulva } \\
\text { B. c. canadensis } \\
\text { B. c. interior } \\
\text { B. c. parvipes }\end{array}$ \\
\hline Hawaiian Goose & Branta sandvicensis & \\
\hline Red-breasted Goose & Branta ruficollis & \\
\hline
\end{tabular}

\section{Network analyses}

A previous phylogenomic analysis of the True Geese indicated high levels of gene tree discordance, which can be caused by hybridization and/or incomplete lineage sorting [12]. To visualize this phylogenetic incongruence, we constructed a phylogenetic neighbour-joining network using the ordinary least squares method (with default settings) in SplitsTree version 4.1.4.2 [15]. This network was based on genetic distances, which were calculated in RAxML 8.3 with a GTR $+\Gamma$ substitution model $[12,37]$. We calculated the degree distributions (i.e. the number of connections for each node in a network) for each genus to quantify the complexity of the networks using the R-package igraph
[47]. The degree distributions for each genus were compared by means of a general linear model with Poisson distribution in $\mathrm{R}$ version 3.2.2.

Hybridization networks are networks that attempt to reconstruct a phylogenetic tree with the fewest amount of hybridization events [15, 48]. For each genus, we combined 3558 gene trees into hybridization networks using the Autumn algorithm [49] with default settings in Dendroscope version 3.4.4 [50].

\section{Demographic analysis}

We conducted a demographic analysis using a hidden Markov model approach as implemented in the software 
package PSMC [51]. A consensus sequence was generated from BAM files using the 'pileup' command in SAMtools [35]. For the PSMC analyses, we used the parameter settings suggested by NadachowskaBrzyska et al. [52], namely "N30 $-\mathrm{t} 5 \quad-\mathrm{r} 5 \quad-\mathrm{p}$ $4+30 * 2+4+6+10$."

\section{Results}

\section{Gene flow analysis}

The D-statistic analysis supported gene flow between several goose species (Table 2 Additional file 5: Table S3). Although the D-statistics for Anser were slightly higher compared to Branta, there was no significant difference (Mann Whitney U, W = 4659, $p=0.088$ ). To infer the timing of gene flow (during or after the diversification), we took advantage of gene tree discordance and constructed histograms based on divergence times of 3558 gene trees. All analyses supported a scenario of gene flow during divergence with low levels of recent gene flow because the histograms all displayed one peak corresponding to the initial species split. The divergence time of several gene trees was close to zero, suggesting low levels of recent gene flow between certain species. Figure 2 shows two examples, involving the Cackling Goose and the Lesser White-fronted Goose (for other species, see Additional file 3: Figure S1).

\section{Network analyses}

The phylogenetic neighbour-joining network (Fig. 3) based on genetic distances uncovered two main clades that corresponded to the genera Anser and Branta. Within these clades, the relationships correspond to previous phylogenetic analyses [12]. The comparison of degree distributions revealed that the Anser-network was more complex compared to the Branta-network (Poisson regression, $\mathrm{SD}=0.1908, z$-value $=-5.08, p$-value $<0.001)$, because the Anser-network contains more nodes with four or five edges compared to the Branta-network. The complexity of the networks was consistent with the suggestion that the evolutionary history of the Anser-clade is more heavily influenced by rapid diversification and hybridization compared to the Branta-clade.

We combined 3558 gene trees into hybridization networks for both genera. These networks attempt to reconstruct a phylogenetic tree with the fewest amount of hybridization events $[15,48]$. Hybridization network analyses of the genus Anser did not result in most likely scenarios, underlining the complexity of introgression and incomplete lineage sorting among Anser species. In the genus Branta, the hybridization network analyses recovered three (not mutually exclusive) scenarios, indicating hybridization events between the Red-breasted Goose and the ancestor of the White-cheeked Geese (i.e. Hawaiian Goose, Canada Goose, Cackling Goose and
Barnacle Goose) and between Red-breasted Goose and Brent Goose (Fig. 4a-b). In addition, one hybridization network (Fig. 4c) suggested a hybrid origin for the Redbreasted Goose. The network suggesting a hybrid origin for this species should not be regarded as definitive proof for hybrid speciation, but rather as a possible scenario that can serve as a starting point for further research.

\section{Demographic analysis}

We reconstructed historical effective populations sizes $\left(\mathrm{N}_{\mathrm{e}}\right)$ for all goose species using the pairwise sequentially Markovian coalescent (PSMC) approach over a range from 1 to 10 million years ago until about 10,000 years ago. Most Anser species (Greater White-fronted Goose, Lesser White-fronted Goose, Tundra Bean Goose, Taiga Bean Goose, Pink-footed Goose, Swan Goose, Greylag Goose, Bar-headed Goose, Snow Goose, and Ross' Goose) and several Branta species (Canada Goose, Cackling Goose, Red-breasted Goose, Pale-bellied Brent Goose and Black Brent Goose) show a steady population increase followed by a dramatic expansion, which suggests population subdivision and occasional gene flow, leading to higher levels of heterozygosity and consequently higher estimates of $\mathrm{N}_{\mathrm{e}}$ [51, 53]. Four species (Hawaiian Goose, Emperor Goose, Barnacle Goose and Dark-bellied Brent Goose) show clear signs of a bottleneck. Figure 5 shows these two patterns as illustrated by Greater White-fronted Goose and Hawaiian Goose (for other species, see Additional file 4: Figure S2).

\section{Discussion}

\section{General patterns of introgression}

Interspecific gene flow is an important aspect in avian speciation [54]. Based on hybridization networks and Dstatistics, calculated from genome-wide data, we found indications for high levels of interspecific gene flow between several goose species. D-statistics allowed us to confidently discriminate between incomplete lineage sorting and interspecific gene flow. The significant D-statistics varied from 0.07 to 0.17 , which is slightly higher compared to analyses on recent radiations, such as Darwin's Finches (0.004-0.092; [55]) and butterflies of the genera Heliconius (0.04; [56]) and Papilio (0.04; [57]). These values do fall within the range of studies on other hybridizing species, such as pigs $(0.11-0.23$; [58]), bears $(0.04-0.46 ;[59,60])$ and Xiphophorus fish (0.03-0.56; [61]).

A significant D-statistic does not necessarily indicate introgression between the species from which the genomes are being compared. There might have been gene flow with an extinct (not sampled) population or the signal might be a remnant from an older hybridization event $[33,62]$. The latter possibility is probably the case for hybridization between Red-breasted Goose and three other species (Hawaiian Goose, Canada Goose and 
Table 2 Significant D-statistics (Z-score $>3$ and $p<0.0001)$ for different combination of three goose species

\begin{tabular}{|c|c|c|c|c|}
\hline P1 & P2 & P3 & D-statistics & Z-score \\
\hline \multicolumn{5}{|l|}{ BRANTA } \\
\hline Barnacle Goose & Cackling Goose & Canada Goose & 0.087 & 4.322 \\
\hline Barnacle Goose & Cackling Goose & Red-breasted Goose & 0.146 & 6.022 \\
\hline Barnacle Goose & Cackling Goose & Black Brent & 0.094 & 3.516 \\
\hline Barnacle Goose & Canada Goose & Red-breasted Goose & 0.1 & 4.037 \\
\hline Barnacle Goose & Hawaii Goose & Red-breasted Goose & 0.094 & 4.192 \\
\hline Barnacle Goose & Black Brent & Red-breasted Goose & 0.073 & 3.022 \\
\hline \multicolumn{5}{|l|}{ ANSER } \\
\hline Lesser White-fronted & Greater White-fronted & Pink-footed Goose & 0.126 & 6.116 \\
\hline Taiga Bean Goose & & & 0.09 & 4.413 \\
\hline Pink-footed Goose & Greater White-fronted & Emperor Goose & 0.088 & 3.701 \\
\hline Tundra Bean Goose & & & 0.079 & 3.383 \\
\hline Taiga Bean Goose & & & 0.128 & 5.457 \\
\hline Greylag Goose & & & 0.079 & 3.537 \\
\hline Taiga Bean Goose & Greater White-fronted & Bar-headed Goose & 0.083 & 3.470 \\
\hline Greater White-fronted & Lesser White-fronted & Swan Goose & 0.114 & 5.279 \\
\hline Pink-footed Goose & & & 0.15 & 6.821 \\
\hline Tundra Bean Goose & & & 0.16 & 8.15 \\
\hline Taiga Bean Goose & & & 0.173 & 8.385 \\
\hline Greater White-fronted & Lesser White-fronted & Ross' Goose & 0.104 & 5.325 \\
\hline Pink-footed Goose & & & 0.12 & 5.421 \\
\hline Tundra Bean Goose & & & 0.103 & 4.682 \\
\hline Taiga Bean Goose & & & 0.083 & 3.93 \\
\hline Swan Goose & & & 0.103 & 3.984 \\
\hline Emperor Goose & & & 0.102 & 4.51 \\
\hline Greater White-fronted & Lesser White-fronted & Snow Goose & 0.165 & 7.336 \\
\hline Pink-footed Goose & & & 0.174 & 7.032 \\
\hline Tundra Bean Goose & & & 0.157 & 7.053 \\
\hline Taiga Bean Goose & & & 0.137 & 6.224 \\
\hline Swan Goose & & & 0.156 & 6.525 \\
\hline Greylag Goose & & & 0.086 & 4.054 \\
\hline Emperor Goose & & & 0.14 & 6.007 \\
\hline Pink-footed Goose & Lesser White-fronted & Emperor Goose & 0.076 & 3.164 \\
\hline Tundra Bean Goose & & & 0.07 & 3.0 \\
\hline Taiga Bean Goose & & & 0.12 & 5.419 \\
\hline Greylag Goose & & & 0.078 & 3.472 \\
\hline Taiga Bean Goose & Pink-footed Goose & Bar-headed Goose & 0.082 & 3.436 \\
\hline Greater White-fronted & Greylag Goose & Ross' Goose & 0.087 & 3.719 \\
\hline Pink-footed Goose & & & 0.107 & 4.496 \\
\hline Tundra Bean Goose & & & 0.086 & 3.408 \\
\hline Swan Goose & & & 0.084 & 3.049 \\
\hline Emperor Goose & & & 0.163 & 6.67 \\
\hline Greater White-fronted & Greylag Goose & Snow Goose & 0.072 & 3.055 \\
\hline Pink-footed Goose & & & 0.091 & 3.416 \\
\hline
\end{tabular}


Table 2 Significant D-statistics (Z-score $>3$ and $p<0.0001$ ) for different combination of three goose species (Continued)

\begin{tabular}{|c|c|c|c|c|}
\hline Emperor Goose & & & 0.139 & 5.59 \\
\hline Emperor Goose & Tundra Bean Goose & Ross' Goose & 0.078 & 3.692 \\
\hline Emperor Goose & Tundra Bean Goose & Snow Goose & 0.074 & 3.317 \\
\hline Emperor Goose & Taiga Bean Goose & Ross' Goose & 0.139 & 6.346 \\
\hline Emperor Goose & Taiga Bean Goose & Snow Goose & 0.139 & 6.655 \\
\hline Taiga Bean Goose & Greylag Goose & Bar-headed Goose & 0.09 & 4.059 \\
\hline
\end{tabular}

Asymmetric gene flow is between P2 and P3. The outgroup for Branta species was a consensus sequence based on all Anser species, while the outgroup for Anser species was a consensus sequence based on all Branta species

Cackling Goose). The hybridization network analysis supported the notion that significant D-statistics were caused by an ancient hybridization event between Redbreasted Goose and the ancestor of these three species. Many of the significant D-statistics in the Anser-clade can probably be explained in the same way, but the complexity of introgression patterns in this clade did not allow us to pinpoint putative hybridization events. In addition, the D-statistic only captures asymmetric gene flow [33]. Because we did not quantify symmetric gene flow, we are probably underestimating the amount of gene flow between the some goose species.

When did this gene flow occur? Further analyses, based on the divergence times of 3558 gene trees, indicated that this gene flow was largely due to ancient hybridization during the diversification of these species.
Ancient gene flow has been reported for a variety of taxa $[46,63,64]$, including several bird groups [55, 65-68]. For instance, Fuchs et al. [65] attributed a conflicting pattern between several loci to ancient hybridization between members of the woodpecker genus Campephilus and the melanerpine lineage (Melanerpes and Sphyrapicus). The increasing number of studies reporting ancient gene flow during species diversification [69] shows that the speciation process is often more complex than, for example, the classical allopatric speciation model [70, 71].

In the allopatric speciation model, populations become geographically isolated and diverge by genetic drift and/or differential selection pressures, resulting in intrinsic reproductive isolation due to the accumulation of DobzhanskyMuller incompatibilities [72, 73]. This speciation model predicts that the distribution of interspecific divergence is

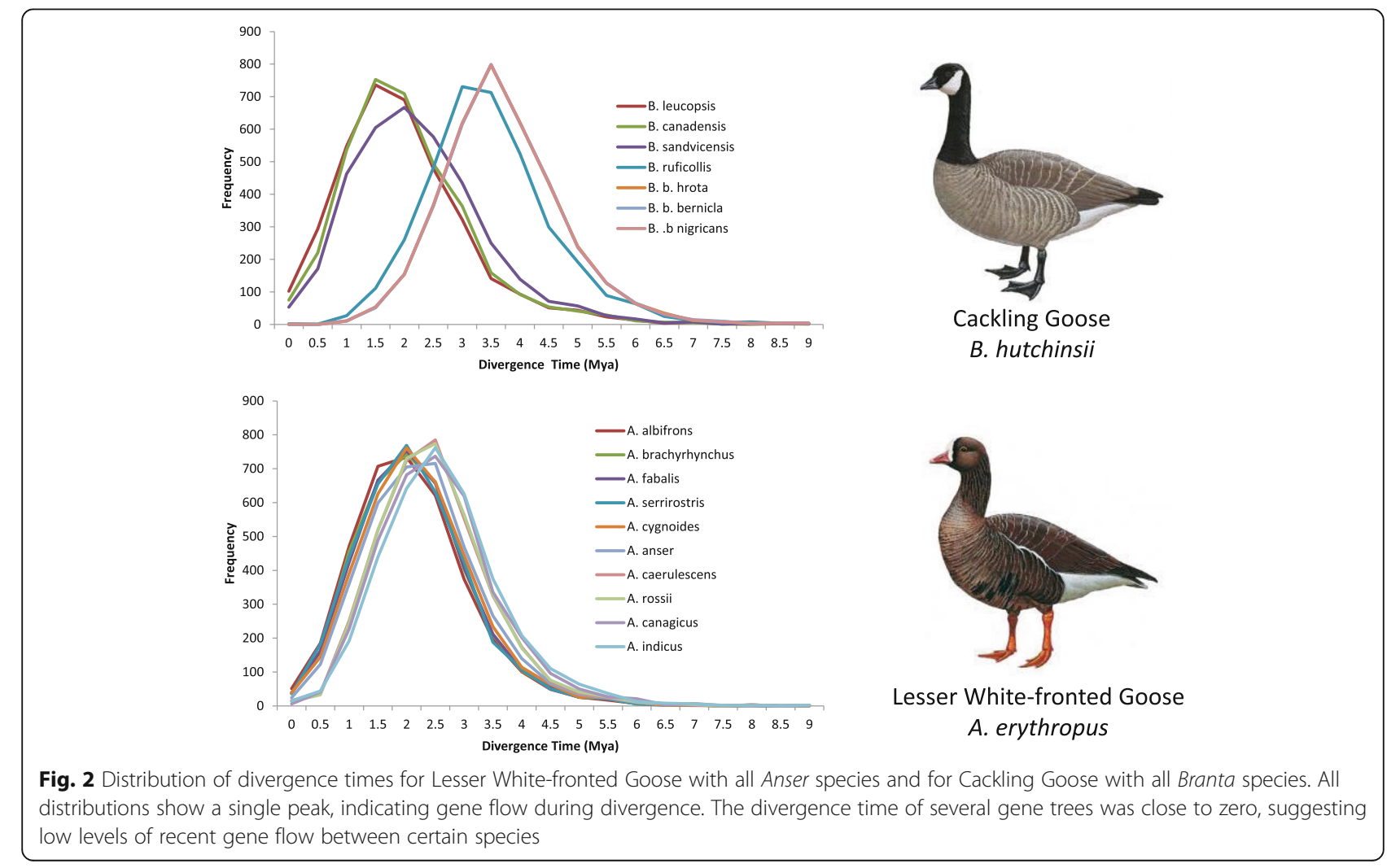




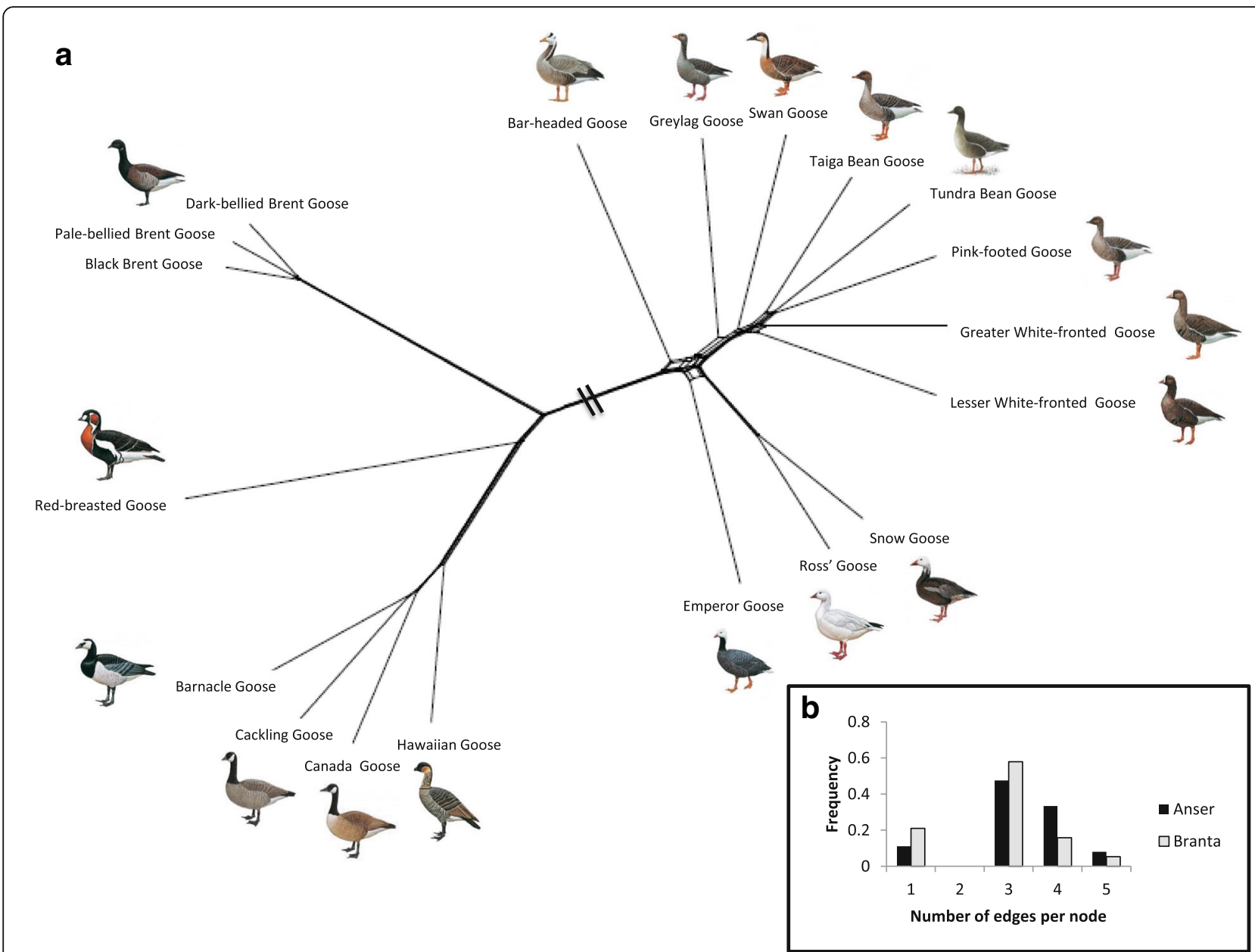

Fig. 3 a Neighbour-joining Network of the True Geese using the ordinary least squares method (with default settings) in SplitsTree version 4.1.4.2 [15], based on genetic distances. $\mathbf{b}$ The comparison of degree distributions indicates that the Anser-network is more complex compared to the Branta-network as it contains relatively more nodes with four and five edges. Drawings used with permission of Handbook of Birds of the World [128]

largely determined by a single, shared species split [74]. But speciation is often more complex: in some cases, speciation may advance by divergent ecological or sexual selection in the face of ongoing gene flow [75], while, in other cases, allopatrically diverging populations may come into secondary contact and hybridize before reproductive isolation is complete [2]. These more complex speciation models predict that interspecific divergence varies considerably across the genome $[6,7]$, because some genomic regions reflect the initial species split time, whereas others indicate more recent genetic exchange $[11,13,76]$.

With regard to the evolutionary history of geese, we found support for a complex speciation model with high levels of gene flow during species diversification. It is, however, not possible to determine whether this gene flow is the outcome of (repeated) secondary contact or divergence-with-gene-flow. ABC modelling based on multiple samples per species allows for the comparison of several scenarios that differ in the amount and timing of gene flow and can thus be used to confidently discriminate between divergence-with-gene-flow and secondary contact [77-79]. For example, Nadachowska-Brzyska et al. [80] compared 15 models (with different patterns and levels of gene flow) to assess the demographic history of Pied Flycatcher (Ficedula hypoleuca) and Collared Flycatcher (Ficedula albicollis). Whole genome re-sequencing data from 20 individuals supported a recent divergence with unidirectional gene flow from Pied Flycatcher into Collared Flycatcher after the Last Glacial Maximum, indicating that the hybrid zone between these species is a secondary contact zone. In this study, we were unable to perform an $\mathrm{ABC}$ modelling exercise because only one individual per species was sampled, while multiple samples per species are required.

Next to evidence for ancient gene flow, our results suggest low levels of recent gene flow, which can be 

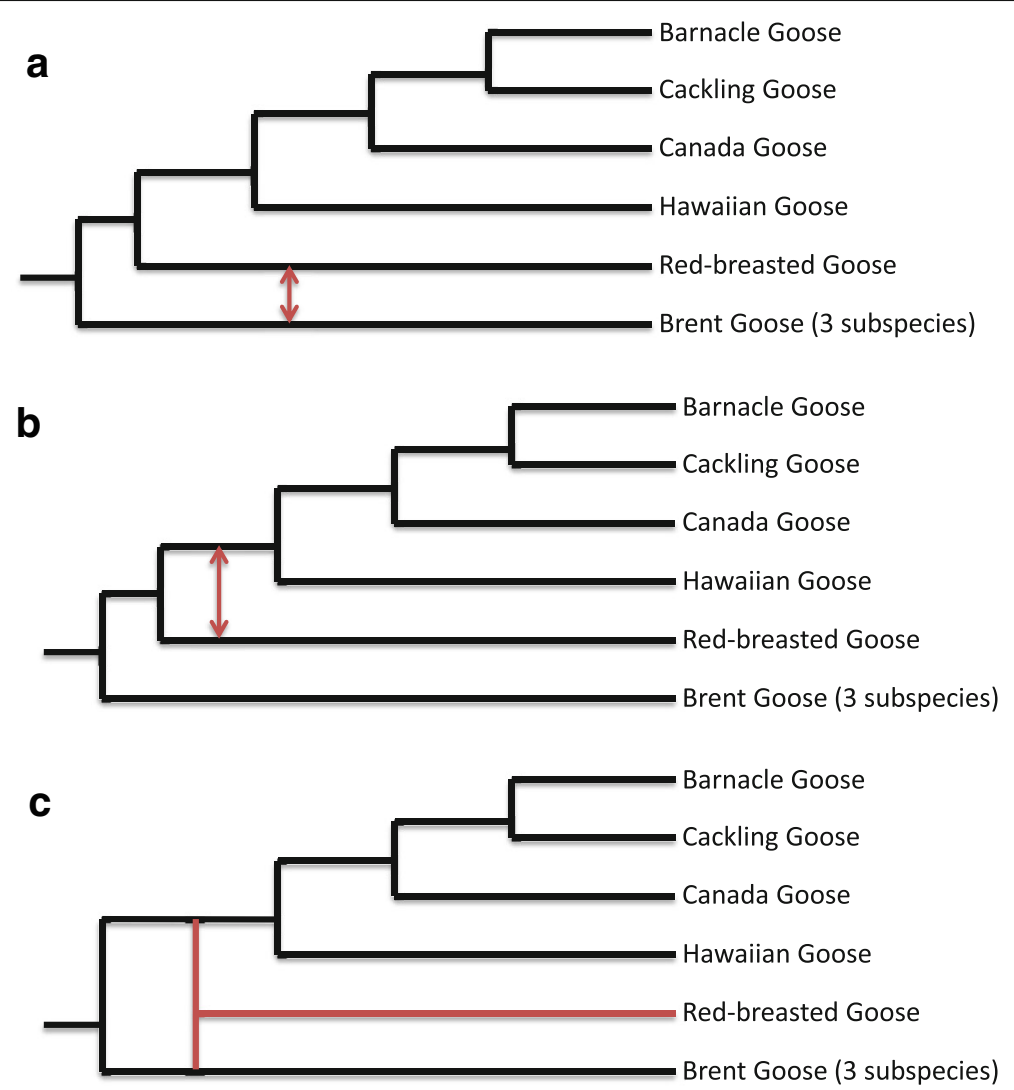

Fig. 4 Hybridization networks for the genus Branta based on the Autumn algorithm [49] in Dendroscope version 3.4.4 [50]. Network a suggests hybridization between Red-breasted Goose and Brent Goose, network b between Red-breasted Goose and the ancestor of the White-cheeked Geese. Network c suggests a hybrid origin for the Red-breasted Goose

explained in three ways. First, the D-statistic analysis may be unable to detect recent gene flow. Indeed, the D-statistic was developed to detect ancient gene flow and to estimate the extent of archaic ancestry in the genomes of extant populations [33]. The detection and quantification of recent gene flow warrants a population genomic approach whereby multiple individuals of one population are sequenced $[3,9,81,82]$. Second, the relative rarity of goose hybrids diminishes the opportunity for backcrossing and introgression, leading to absence or low levels of recent gene flow [19]. Third, there may be little recent gene flow because of strong intrinsic and/or extrinsic selection against goose hybrids. Although most goose hybrids are viable and fertile [19], second generation hybrids or backcrosses may be impaired by genetic incompatibilities $[83,84]$, or hybrids might be ecologically maladapted (e.g., intermediate beak morphology) or unable to find a mate [73]. To answer these questions, field observations are needed, which is challenging given the relative rarity of hybrids [19] and the difficulty of identifying certain hybrids [85]. Strong selection against hybrids might also suggest that the diversification of the True Geese was partly driven by reinforcement [86].

\section{Demographic patterns}

The reconstruction of historical effective populations sizes $\left(\mathrm{N}_{\mathrm{e}}\right)$ for all goose species using the pairwise sequentially Markovian coalescent (PSMC) approach indicated two main patterns. First, most species showed a steady increase during the Pliocene and Pleistocene followed by population subdivision (apparent as a dramatic increase in $\mathrm{N}_{\mathrm{e}}$ ) during the Last Glacial Maximum (LGM, about 110,000 to 12,000 years ago). The increase in population size during the Pliocene and Pleistocene can be explained by a global cooling trend which resulted in the formation of a circumpolar tundra and the emergence of temperate grasslands [87-89]. The tundra habitat acted as breeding ground [90], whereas the grasslands served as wintering grounds where mate choice occurred [91], enabling goose populations to proliferate. In addition, the climatic fluctuations during the Pliocene and Pleistocene might have instigated range expansions and shifts. This combination of large $\mathrm{N}_{e}$ and occasional range shifts might have facilitated contact between the diverging goose species, resulting in the establishment of numerous hybrids zones and consequent gene flow $[92,93]$. 

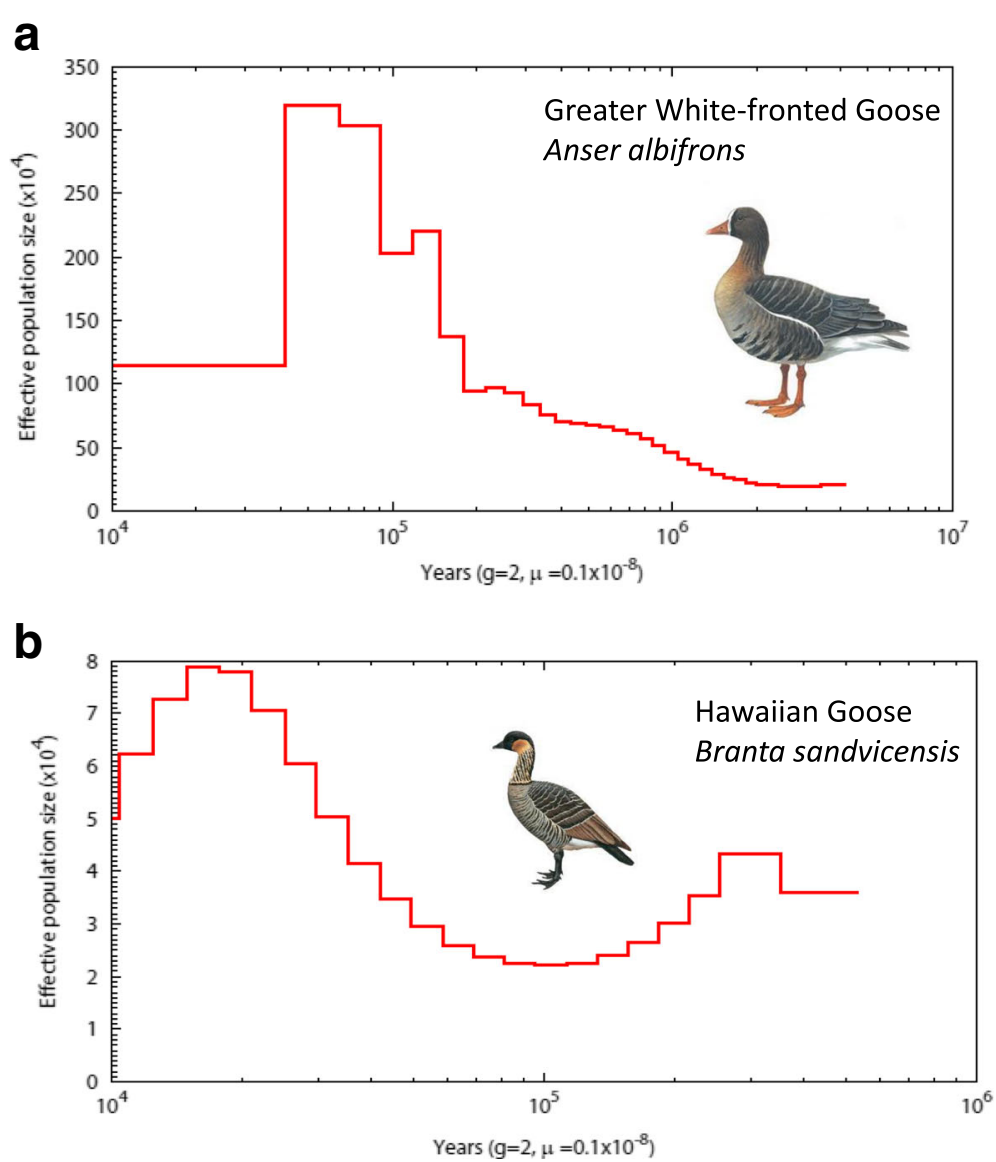

Fig. 5 Examples of two general demographic patterns for the True Geese based on PSMC analyses. a Steady population increase followed by dramatic expansion which suggests population subdivision, as illustrated by Greater White-fronted Goose. b Population bottleneck after island colonization, as illustrated by Hawaiian Goose

During the LGM, many plant and animal populations were subdivided into separate refugia by the ice sheets that expanded from the north [94, 95]. This population subdivision has been described for several goose species [96] and the genetic signature of this subdivision has been uncovered for certain species, such as Pink-footed Goose [97], Bean Goose [98], Greater White-fronted Goose [99, 100], Canada Goose [101], and Snow Goose [26, 102].

Four species show a decrease in $\mathrm{Ne}$ and a consequent genetic bottleneck in the PSMC analyses, which suggests island colonization. Indeed, these four goose species have colonized island habitats: the Hawaiian Goose reached the Hawaiian archipelago [103], the Emperor Goose settled on the Aleutian Islands [104], and the Barnacle Goose and the Dark-bellied Brent Goose established populations on arctic islands in the North Atlantic, such as Spitsbergen and Novaya Zemlya [105]. It is well-established that island colonization leads to a reduction in heterozygosity and $\mathrm{N}_{\mathrm{e}}$ [106], and that island populations have lower levels of genetic variation compared to mainland species [107]. Genetic bottlenecks following island colonization have been documented for numerous other bird species (e.g., [108, 109]). However, further analyses are warranted to confirm these scenarios of island colonization. For instance, comparing the genetic diversity of these four goose species with closely related mainland populations.

\section{Comparing Anser and Branta}

There is a striking contrast in the patterns of introgression between the two genera. As hypothesised, the general network analysis showed that the Anser-network is more complex than the Branta-network and D-statistics were slightly (although not significantly) higher in the Anser-clade. While high levels of gene flow hindered the precise reconstruction of hybridization events in the Anser-clade, it was possible to pinpoint several putative hybridization events within Branta-clade. The hybridization network analyses provided evidence for gene flow between the Red-breasted Goose and the ancestor of the White-cheeked Geese (i.e. Hawaiian Goose, Canada Goose, Cackling Goose and Barnacle Goose), between Red-breasted Goose and Brent 
Goose, and between Canada Goose and Cackling Goose. Past gene flow between the latter two species has been reported previously [23]. What factors can explain the differential introgression patterns between Anser and Branta? We will consider three possible factors: (1) macroevolutionary dynamics, (2) morphological and behavioural differences, and (3) demographic dynamics.

First, these patterns of introgression were reconstructed by comparing the genomes of modern, extant species. The ancestors of these modern species may have interbred with unknown extinct species. It might thus be possible that the evolutionary history of the Brantaclade was as influenced by hybridization as much as the diversification of the Anser-clade, but that many Brantaspecies have become extinct. For example, the Hawaiian radiation of Branta geese consisted of at least three species, of which only the Hawaiian Goose remains today [103]. The different introgression patterns (as observed by comparing extant genomes) could then be attributed to differences in extinction rates between the genera. Unfortunately, the fossil record for geese is currently still too sparse to test this hypothesis $[110,111]$.

Second, differential introgression patterns may be explained by differences in behaviour [112, 113]. Although the behaviour of extant species does not necessarily correspond to the ancestral behaviour, we can speculate about possible differences between the genera. Pair formation, involving several pre-copulatory displays, and copulation vary little between the species and the genera $[90,114]$, which can explain the frequent occurrence of hybridization on the species level, but does not clarify the differences in introgression patterns between the genera. Are there differences in certain behaviours that lead to hybridization, such as interspecific nest parasitism or forced extra-pair copulations [115]? These behaviours have been observed in both genera, but the relative contribution of each behaviour to the occurrence of goose hybrids remains to be quantified [19].

Mate choice in waterfowl is largely determined by sexual imprinting [116]. Anser species are morphologically more similar compared to Branta species, which might increase the probability of heterospecific mate choice. Based on this reasoning, we expect more Anser hybrids compared to Branta. This expectation remains to be tested, but will be challenging because hybrids between morphologically similar species are difficult to identify [85] and many goose hybrids are probably of captive origin [19].

Third, differences in demographic dynamics, mediated by a particular biogeographical and climatic context, might determine the frequency of interspecific interactions, possibly leading to introgressive hybridization. The Anserclade has a largely Eurasian distribution (with the exception of Snow Goose and Ross' Goose). The open tundra landscape of Eurasia during the Pleistocene allowed for large effective population sizes and the climatic fluctuations during the Pliocene and Pleistocene might have instigated range expansions and shifts. In contrast to the Anser-clade, the Branta species are more widely distributed across the Northern Hemisphere: Canada Goose and Cackling Goose in North America, Hawaiian Goose on the Hawaiian islands, Barnacle Goose and Red-breasted Goose in Eurasia, and the circumpolar Brent Goose. This distribution limits the frequency of interspecific contact, although several species could achieve large effective population sizes.

The demographic differences between the genera might also lead to other speciation histories. The diversification of the Branta-clade was more gradual compared to the Anser-clade, which can be considered an adaptive radiation [12]. During an adaptive radiation the frequency of interspecific interactions increases, enhancing the probability of introgressive hybridization [117]. Moreover, as the radiation progresses, occasional hybridization could facilitate further ecological diversification [118]. Possibly, the diversification in beak morphology among Anser species was driven by hybridization, comparable to the radiation of Darwin's Finches on the Galapagos Islands [55, 119].

\section{A hybrid origin for the Red-breasted Goose?}

The hybridization network analysis also suggested a possible alternative scenario in which the Red-breasted Goose is a hybrid species between the ancestors of the White-cheeked Geese and the Brent Goose. If so, the distinct morphology of this species, which is not intermediate between its putative parents, might be the outcome of transgressive segregation [120]. But indisputably demonstrating hybrid speciation is challenging and often the most likely scenario for the observed genomic pattern is introgressive hybridization [121]. To our knowledge, five bird species have been proposed to have hybrid origins: the Italian Sparrow (Passer italiae, [122]), the Audubon's Warbler (Setophaga auduboni, [123]), the Genovesa Mockingbird (Mimus parvulus bauri, [124]), the Hawaiian Duck (Anas wylvilliana, [125]) and a recent lineage of Darwin's finches on Daphne Major (referred to as 'Big Bird', [126]). However, the hybrid origin of these putative cases has not been unequivocally established [121]. Also, in the case of the Red-breasted Goose, the most parsimonious explanation seems to involve separate hybridization events between the Red-breasted Goose and the ancestor of the White-cheeked Geese and between Red-breasted Goose and Brent Goose. If the Red-breasted Goose is a hybrid species, one would expect significantly higher values for D-statistics. For example, a recent genomic study of the Italian Sparrow, a hybrid species between House Sparrow (Passer domesticus) and Spanish Sparrow (Passer hispaniolensis), uncovered D-statistics over 50\% [127]. The highest value 
for Red-breasted Goose in our analysis was about 15\% (even some Anser species displayed higher D-statistics). Hence, a hybrid origin for the Red-breasted Goose seems unlikely.

\section{Conclusions}

Using genomic datasets and modern analysis tools, such as the D-statistic and PSMC analysis, in combination with network analyses based on gene tree discordance, we were able to determine patterns of introgressive hybridization in the True Geese. High levels of ancient gene flow suggest a scenario of divergence-with-geneflow. We found indications for low levels of recent gene flow, but the quantification of this recent gene flow warrants a population genomic approach whereby multiple individuals of one population are sequenced. The reconstruction of historical effective population sizes indicates that most species showed a steady increase during the Pliocene and Pleistocene followed by population subdivision during the Last Glacial Maximum about 110,000 to 12,000 years ago. The combination of large effective population sizes and occasional range shifts might have facilitated contact between diverging goose species, resulting in the establishment of numerous hybrid zones and consequent gene flow. Our approach, based on genome-wide phylogenetic incongruence and network analyses, will be a useful procedure to reconstruct the complex evolutionary histories of many naturally hybridizing species groups.

\section{Additional files}

\section{Additional file 1: Table S1. Sampled goose species and sampling} location. (DOCX $15 \mathrm{~kb}$ )

Additional file 2: Table S2. Mapping results of all goose samples to Mallard genome (version 73) using SMALT. (DOCX $20 \mathrm{~kb}$ )

Additional file 3: Table S3. D-statistics for all combinations of three species per genus. Significant D-statistics (Z-score $>4$ ), suggesting gene flow between $\mathrm{P} 2$ and $\mathrm{P} 3$, are indicated in bold and colored in yellow. The outgroup for Branta was a consensus sequence based on all Anser species. Similarly, the outgroup for Anser was a consensus sequence based on all Branta species. (DOCX $19 \mathrm{~kb}$ )

Additional file 4: Figure S1. Distribution of gene tree divergence times for all goose species. All distributions show a single peak, indicating gene flow during divergence. The divergence time of several gene trees was close to zero, suggesting low levels of recent gene flow between certain species. Final three figures represent the three subspecies of Brent Goose, which is depicted in the lower right panel. (ZIP $2715 \mathrm{~kb}$ )

Additional file 5: Figure S2. Estimates of historical effective population sizes for all goose species, based on a PSMC analysis. Final three figures represent the three subspecies of Brent Goose, which is depicted in the lower right panel. (ZIP $766 \mathrm{~kb})$

\section{Abbreviations}

ABC Modelling: Approximate Bayesian Computation Modelling; Bp: Base pairs; GATK: Genome Analysis Toolkit; GTR: General Time-reversible; IUPAC: International Union of Pure and Applied Chemistry; LGM: Last Glacial Maximum; $\mathrm{N}_{\mathrm{e}}$ : Effective Population Size; PSMC: Pairwise Sequentially Markovian Coalescent; SD: Standard Deviation

\section{Acknowledgments}

We are indebted to Gerard Müskens, Jurre Brenders, Henk en Wim Meinen, Ouwehands Zoo (Gerard Meijer), Avifauna (Jan Harteman \& Joost Lammers) and the Nederlands Instituut voor Ecologie (NIOO-KNAW) for their help during the collection of blood samples, and to Kimberley Laport for the DNA extraction.

Funding

This study was funded by Stichting de Eik.

\section{Availability of data and materials}

The dataset supporting the conclusions of this article are available at Bioproject PRJEB20373 (http://www.ebi.ac.uk/ena/data/view/PRJEB20373) at the European Nucleotide Archive (ENA).

\section{Authors' contributions \\ JO collected the blood samples, analysed the genomic data, and wrote the manuscript. RPMAC guided the DNA extraction and sequencing. H-JM, RHSK, $\mathrm{PH}, \mathrm{SEW}, \mathrm{RCY}, \mathrm{MAMG}$ and HHTP. commented on earlier versions of the manuscript. All authors read and approved the final manuscript.}

\section{Ethics approval and consent to participate}

The collection of blood samples (Submission 2,013,001.b) has been approved by the Ethical Committee for Animal Experiments

(Dierexperimentencommissie [DEC]) at Wageningen University.

\section{Consent for publication}

Not applicable.

\section{Competing interests}

The authors declare that they have no competing interests.

\section{Publisher's Note}

Springer Nature remains neutral with regard to jurisdictional claims in published maps and institutional affiliations.

\section{Author details}

${ }^{1}$ Resource Ecology Group, Wageningen University \& Research, Droevendaalsesteeg 3a, 6708 PB Wageningen, the Netherlands. ${ }^{2}$ Animal Breeding and Genomics, Wageningen University \& Research,

Droevendaalsesteeg 1, 6708 PB Wageningen, the Netherlands. ${ }^{3}$ Department of Migration and Immuno-Ecology, Max Planck Institute for Ornithology, Am Obstberg, 1D-78315 Radolfzell, Germany. ${ }^{4}$ Department of Biology, University of Konstanz, D-78457 Constance, Germany. ${ }^{5}$ Centre for Wildlife Ecology, Simon Fraser University, V5A 156, Burnaby, BC, Canada.

Received: 11 April 2017 Accepted: 11 August 2017

Published online: 22 August 2017

References

1. Abbott R, et al. Hybridization and speciation. J Evol Biol. 2013;26(2):229-46.

2. Seehausen $\mathrm{O}$, et al. Genomics and the origin of species. Nat Rev Genet. 2014;15(3):176-92.

3. Toews DPL, et al. Genomic approaches to understanding population divergence and speciation in birds. Auk. 2016;133(1):13-30.

4. Kraus $\mathrm{RH}$, Wink M. Avian genomics: fledging into the wild! J Ornithol. 2015; 156(4):1-15

5. Jarvis ED. Perspectives from the Avian Phylogenomics Project: Questions that Can Be Answered with Sequencing All Genomes of a Vertebrate Class. Ann Rev Animal Biosci. 2016;4:45-59.

6. Nosil P, Funk DJ, Ortiz-Barrientos D. Divergent selection and heterogeneous genomic divergence. Mol Ecol. 2009;18(3):375-402.

7. Nosil P, Feder JL. Widespread yet heterogeneous genomic divergence. Mol Ecol. 2012;21(12):2829-32.

8. Harrison RG, Larson EL. Heterogeneous genome divergence, differential introgression, and the origin and structure of hybrid zones. Mol Ecol. 2016; 25:2454-66.

9. Ellegren $\mathrm{H}$, et al. The genomic landscape of species divergence in Ficedula flycatchers. Nature. 2012;491(7426):756-60.

10. Maddison WP. Gene trees in species trees. Syst Biol. 1997;46(3):523-36.

11. Payseur BA. Using differential introgression in hybrid zones to identify genomic regions involved in speciation. Mol Ecol Resour. 2010;10(5):806-20. 
12. Ottenburghs J, et al. A tree of geese: A phylogenomic perspective on the evolutionary history of True Geese. Mol Phylogenet Evol. 2016;101:303-13.

13. Harrison RG, Larson EL. Hybridization, Introgression, and the Nature of Species Boundaries. J Hered. 2014;105:795-809.

14. Ottenburghs J, et al. Birds in a bush: Toward an avian phylogenetic network. Auk. 2016;133:577-82.

15. Huson DH, Bryant D. Application of phylogenetic networks in evolutionary studies. Mol Biol Evol. 2006;23(2):254-67.

16. Suh A, Smeds L, Ellegren $H$. The Dynamics of Incomplete Lineage Sorting across the Ancient Adaptive Radiation of Neoavian Birds. PLoS Biol. 2015; 13(8):e1002224.

17. Jarvis ED, et al. Whole-genome analyses resolve early branches in the tree of life of modern birds. Science. 2014;346(6215):1320-31.

18. McCarthy EM. Handbook of avian hybrids of the world. Oxford, New York: Oxford University Press. xiv; 2006. 583 p.

19. Ottenburghs J, et al. Hybridization in geese: a review. Front Zool. 2016; 13(1):1-9.

20. Delacour J, Mayr E. The family Anatidae. Wilson Bull. 1945;57(1):3-55

21. Delnicki D. Ross Goose Snow Goose Hybrid in South Texas. Auk. 1974;91(1):174.

22. Hatch DRM, Shortt AH. Possible Intermediate Ross Goose and Snow Goose in Manitoba. Auk. 1976;93(2):391-2.

23. Leafloor JO, Moore JA, Scribner KT. A Hybrid Zone between Canada Geese (Branta canadensis) and Cackling Geese (B. hutchinsii). Auk. 2013;130(3):487-500.

24. Nijman V, Aliabadian M, Roselaar CS. Wild hybrids of Lesser Whitefronted Goose (Anser erythropus) x Greater White-fronted Goose (A. albifrons) (Aves: Anseriformes) from the European migratory flyway. Zool Anz. 2010;248(4):265-71.

25. Trauger DL, Dzubin A, Ryder JP. White Geese Intermediate between Ross' Geese and Lesser Snow Geese. Auk. 1971;88(4):856.

26. Weckstein JD, et al. Hybridization and population subdivision within and between Ross's Geese and Lesser Snow Geese: A molecular perspective. Condor. 2002;104(2):432-6.

27. Lehmhus J, Gustavsson CG. Hybrids between Bar-headed Goose Anser indicus and Snow Goose Anser caerulescens. Ornis Scvecica. 2014;24:147-63.

28. Craven SR, Westemeier RL. Probable Canada Goose x White-fronted Goose Hybrids. Wilson Bulletin. 1979;91(4):628-9.

29. Nelson HK. Hybridization of Canada Geese with Blue Geese in the wild. Auk. 1952;69(4):425-8.

30. Prevett JP, Macinnes CD. Observations of Wild Hybrids between Canada and Blue Geese. Condor. 1973;75(1):124-5.

31. Gustavsson CG. Images of Barnacle Goose Branta leucopsis hybrids - a photo documentation of some crosses with different Anser species. Ornis Svecica. 2009;19(1):19-31.

32. Ruokonen M, Kvist L, Lumme J. Close relatedness between mitochondrial DNA from seven Anser goose species. J Evol Biol. 2000;13(3):532-40.

33. Durand EY, et al. Testing for Ancient Admixture between Closely Related Populations. Mol Biol Evol. 2011;28(8):2239-52.

34. Huang $\mathrm{YH}$, et al. The duck genome and transcriptome provide insight into an avian influenza virus reservoir species. Nat Genet. 2013;45(7):776-83.

35. Li H, et al. The Sequence Alignment/Map format and SAMtools. Bioinformatics. 2009;25(16):2078-9.

36. McKenna A, et al. The Genome Analysis Toolkit: a MapReduce framework for analyzing next-generation DNA sequencing data. Genome Res. 2010;20(9): 1297-303.

37. Stamatakis A. RAxML-VI-HPC: Maximum likelihood-based phylogenetic analyses with thousands of taxa and mixed models. Bioinformatics. 2006; 22(21):2688-90.

38. Stamatakis A, Hoover $\mathrm{P}$, Rougemont J. A rapid bootstrap algorithm for the RAxML Web servers. Syst Biol. 2008;57(5):758-71.

39. Green RE, et al. A Draft Sequence of the Neandertal Genome. Science. 2010; 328(5979):710-22

40. Tajima F. Evolutionary Relationship of DNA-Sequences in Finite Populations. Genetics. 1983;105(2):437-60.

41. Hudson RR. Testing the Constant-Rate Neutral Allele Model with ProteinSequence Data. Evolution. 1983:37(1):203-17.

42. Ward BJ, van Oosterhout C. hybridcheck: software for the rapid detection, visualization and dating of recombinant regions in genome sequence data. Mol Ecol Resour. 2016;16(2):534-9.

43. Britton T, et al. Estimating divergence times in large phylogenetic trees. Syst Biol. 2007;56(5):741-52.
44. Fulton $T L$, Letts $B$, Shapiro B. Multiple losses of flight and recent speciation in steamer ducks. Proc Royal Soc B-Biol Sci. 2012;279(1737):2339-46.

45. Jetz W, et al. The global diversity of birds in space and time. Nature. 2012; 491(7424):444-8.

46. Li G, et al. Phylogenomic evidence for ancient hybridization in the genomes of living cats (Felidae). Genome Res. 2016;26(1):1-11.

47. Csardi, G. and T. Nepusz, The igraph software package for complex network research. InterJournal, Complex Systems, 2006: p. 1695.

48. Chen ZZ, Wang L, Yamanaka S. A fast tool for minimum hybridization networks. BMC Bioinformatics. 2012;13:155.

49. Huson, D. and S. Linz, Autumn Algorithm-Computation of Hybridization Networks for Realistic Phylogenetic Trees. 2016.

50. Huson DH, Scornavacca C. Dendroscope 3: An Interactive Tool for Rooted Phylogenetic Trees and Networks. Syst Biol. 2012;61(6):1061-7.

51. Li H, Durbin R. Inference of human population history from individual whole-genome sequences. Nature. 2011;475(7357):493-U84.

52. Nadachowska-Brzyska K, et al. Temporal Dynamics of Avian Populations during Pleistocene Revealed by Whole-Genome Sequences. Curr Biol. 2015;25(10):1375-80.

53. Jeong CW, et al. Admixture facilitates genetic adaptations to high altitude in Tibet. Nat Commun. 2014;5

54. Rheindt FE, Edwards SV. Genetic Introgression: An Integral but Neglected Component of Speciation in Birds. Auk. 2011;128(4):620-32.

55. Lamichhaney $S$, et al. Evolution of Darwin's finches and their beaks revealed by genome sequencing. Nature. 2015;518(7539):371-5.

56. Dasmahapatra KK, et al. Butterfly genome reveals promiscuous exchange of mimicry adaptations among species. Nature. 2012;487(7405):94-8.

57. Zhang W, Kunte K, Kronforst MR. Genome-Wide Characterization of Adaptation and Speciation in Tiger Swallowtail Butterflies Using De Novo Transcriptome Assemblies. Genome Biol Evol. 2013;5(6):1233-45.

58. Frantz, L.A.F., et al., Genome sequencing reveals fine scale diversification and reticulation history during speciation in Sus. Genome Biol, 2013. 14(9).

59. Liu SP, et al. Population Genomics Reveal Recent Speciation and Rapid Evolutionary Adaptation in Polar Bears. Cell. 2014;157(4):785-94.

60. Cahill JA, et al. Genomic evidence of geographically widespread effect of gene flow from polar bears into brown bears. Mol Ecol. 2015;24(6):1205-17.

61. Cui RF, et al. Phylogenomics Reveals Extensive Reticulate Evolution in Xiphophorus Fishes. Evolution. 2013;67(8):2166-79.

62. Schumer $M$, et al. Ancient hybridization and genomic stabilization in a swordtail fish. Mol Ecol. 2016;25(11):2661-79.

63. Kutschera $V E$, et al. Bears in a forest of gene trees: phylogenetic inference is complicated by incomplete lineage sorting and gene flow. Mol Biol Evol. 2014;31(8):2004-17.

64. Brennan IG, Bauer AM, Jackman TR. Mitochondrial introgression via ancient hybridization, and systematics of the Australian endemic pygopodid gecko genus Delma. Mol Phylogenet Evol. 2016;94(Pt B):577-90.

65. Fuchs J, et al. A multi-locus phylogeny suggests an ancient hybridization event between Campephilus and melanerpine woodpeckers (Ayes: Picidae). Mol Phylogenet Evol. 2013;67(3):578-88.

66. McCormack JE, Venkatraman MX. A Distinctive Genetic Footprint of Ancient Hybridization. Auk. 2013;130(3):469-75.

67. Rheindt FE, Christidis L, Norman JA. Genetic introgression, incomplete lineage sorting and faulty taxonomy create multiple cases of polyphyly in a montane clade of tyrant-flycatchers (Elaenia, Tyrannidae). Zool Scr. 2009;38(2):143-53.

68. Wang, W.J., et al., Past hybridization between two East Asian long-tailed tits (Aegithalos bonvaloti and A. fuliginosus). Front Zool, 2014. 11.

69. Pinho C, Hey J. Divergence with Gene Flow: Models and Data. Annu Rev Ecol Evol Syst. 2010;41:215-30.

70. Dobzhansky T. Genetics and the origin of species. New York: Columbia University Press; 1937.

71. Mayr, E., Systematics in the origin of species : from the viewpoint of a zoologist. Columbia biological series;no. 13. 1942, New York: Harvard University Press.

72. Muirhead CA, Presgraves DC. Hybrid Incompatibilities, Local Adaptation, and the Genomic Distribution of Natural Introgression between Species. Am Nat. 2016:187(2):249-61

73. Coyne, J.A. and H.A. Orr, Speciation. 2004, Sunderland, MA: Sinauer Associates, Inc.

74. Wilkinson-Herbots HM. The distribution of the coalescence time and the number of pairwise nucleotide differences in the "isolation with migration" model. Theor Popul Biol. 2008;73(2):277-88. 
75. Nosil, P., Ecological speciation. Oxford series in ecology and evolution. 2012, Oxford: Oxford University Press.

76. Wu Cl. The genic view of the process of speciation. J Evol Biol. 2001; 14(6):851-65.

77. Smyth JF, Patten MA, Pruett CL. The evolutionary ecology of a species ring: a test of alternative models. Folia Zool. 2015;64(3):233-44.

78. Raposo do Amaral F, et al. Multilocus tests of Pleistocene refugia and ancient divergence in a pair of Atlantic Forest antbirds (Myrmeciza). Mol Ecol. 2013;22(15):3996-4013.

79. Yeung CKL, et al. Testing Founder Effect Speciation: Divergence Population Genetics of the Spoonbills Platalea regia and P. minor (Threskiornithidae, Aves). Mol Biol Evol. 2011;28(1):473-82.

80. Nadachowska-Brzyska, K., et al., Demographic Divergence History of Pied Flycatcher and Collared Flycatcher Inferred from Whole-Genome Resequencing Data. PLoS Genet, 2013. 9(11)

81. Lavretsky P, et al. Becoming pure: identifying generational classes of admixed individuals within lesser and greater scaup populations. Mol Ecol. 2016;25(3):661-74.

82. Poelstra JW, et al. The genomic landscape underlying phenotypic integrity in the face of gene flow in crows. Science. 2014;344(6190):1410-4.

83. Arrieta RS, Lijtmaer DA, Tubaro PL. Evolution of postzygotic reproductive isolation in galliform birds: analysis of first and second hybrid generations and backcrosses. Biol J Linn Soc. 2013;110(3):528-42.

84. Lijtmaer DA, Mahler B, Tubaro PL. Hybridization and postzygotic isolation patterns in pigeons and doves. Evolution. 2003;57(6):1411-8.

85. Randler C. Frequency of bird hybrids: does detectability make all the difference? J Ornithol. 2004;145(2):123-8.

86. Servedio MR, Noor MAF. The role of reinforcement in speciation: Theory and data. Annu Rev Ecol Evol Syst. 2003;34:339-64.

87. Zachos J, et al. Trends, rhythms, and aberrations in global climate $65 \mathrm{Ma}$ to present. Science. 2001;292(5517):686-93.

88. Prins HHT. The origins and development of grassland communities in northwestern Europe. In: Wallis de Vries MF, Bakker JP, van Wieren SE, editors. Grazing and Conservation Management. Boston: Kluwer Academic Publishers; 1998. p. 55-105.

89. Kahlke RD. The origin of Eurasian Mammoth Faunas (Mammuthus coelodonta Faunal Complex). Quat Sci Rev. 2014;96:32-49.

90. Owen M. Wild geese of the world : their life history and ecology. London: Batsford; 1980

91. Rodway MS. Timing of pairing in waterfowl I: Reviewing the data and extending the theory. Waterbirds. 2007;30(4):488-505.

92. Chunco AJ. Hybridization in a warmer world. Ecol Evol. 2014;4(10):2019-31.

93. Buggs RJA. Empirical study of hybrid zone movement. Heredity. 2007;99(3):301-12.

94. Hewitt G. The genetic legacy of the Quaternary ice ages. Nature. 2000; 405(6789):907-13.

95. Hewitt GM. Some genetic consequences of ice ages, and their role in divergence and speciation. Biol J Linn Soc. 1996;58(3):247-76.

96. Ploeger PL. Geographical Differentation in Artic Anatidae as a Result of Isolation During the Last Glacial. 1968. EJ Brill.

97. Ruokonen M, Aarvak T, Madsen J. Colonization history of the high-arctic pink-footed goose Anser brachyrhynchus. Mol Ecol. 2005;14(1):171-8.

98. Ruokonen M, Litvin K, Aarvak T. Taxonomy of the bean goose-pink-footed goose. Mol Phylogenet Evol. 2008;48(2):554-62.

99. Eda M, et al. Phylogenetic relationship of the Greater White-fronted Goose Anser albifrons subspecies wintering in the Palaearctic region. Ornithol Sci. 2013;12(1):35-42.

100. Ely $C R$, et al. Circumpolar variation in morphological characteristics of Greater White-Fronted Geese Anser albifrons. Bird Study. 2005;52:104-19.

101. Scribner KT, et al. Phylogeography of Canada Geese (Branta canadensis) in western North America. Auk. 2003;120(3):889-907.

102. Quinn T. The genetic legacy of Mother Goose-phylogeographic patterns of lesser snow goose Chen caerulescens caerulescens maternal lineages. Mol Ecol. 1992;1(2):105-17.

103. Paxinos EE, et al. mtDNA from fossils reveals a radiation of Hawaiian geese recently derived from the Canada goose (Branta canadensis). Proc Natl Acad Sci U S A. 2002:99(3):1399-404

104. Eisenhauer DI, Kirkpatrick CM. Ecology of Emperor Goose in Alaska. Wildl Monogr. 1977:57:6-62

105. Madsen, J., G. Cracknell, and T. Fox, Goose populations of the Western Palearctic : a review of status and distribution. Wetlands International publication. Vol. 48. 1999, Wageningen: Wetlands International.
106. Nei M, Maruyama T, Chakraborty R. Bottleneck Effect and Genetic-Variability in Populations. Evolution. 1975;29(1):1-10.

107. Frankham R. Do island populations have less genetic variation than mainland populations? Heredity. 1997;78:311-27.

108. Spurgin LG, et al. Genetic and phenotypic divergence in an island bird: isolation by distance, by colonization or by adaptation? Mol Ecol. 2014;23(5):1028-39.

109. Clegg SM, et al. Genetic consequences of sequential founder events by an island-colonizing bird. Proc Natl Acad Sci U S A. 2002;99(12):8127-32.

110. Mlíkovský J. Cenozoic birds of the world Part 1: Europe. Praha: Ninox Press; 2002.

111. Brodkorb, P., Catalogue of fossil birds: Part 2 (Anseriformes through Galliformes). 1964: University of Florida.

112. Wirtz P. Mother species-father species: unidirectional hybridization in animals with female choice. Anim Behav. 1999;58:1-12.

113. Randler C. Behavioural and ecological correlates of natural hybridization in birds. Ibis. 2006;148(3):459-67.

114. Johnsgard PA. Handbook of waterfowl behavior. Ithaca, N.Y: Comstock Pub. Associates. xiv; 1965. 378 p.

115. Randler C. Do forced extrapair copulations and interspecific brood amalgamation facilitate natural hybridisation in wildfowl? Behaviour. 2005;142:477-88.

116. Rohwer, F.C. and M.G. Anderson, Female-biased philopatry, monogamy, and the timing of pair formation in migratory waterfowl, in Current Ornithology. 1988, Springer. p. 187-221.

117. Seehausen O. Hybridization and adaptive radiation. Trends Ecol Evol. 2004; 19(4):198-207.

118. Gilbert, L., Adaptive novelty through introgression in Heliconius wing patterns: evidence for shared genetic "tool box" from synthetic hybrid zones and a theory of diversification. Ecology and Evolution Taking Flight: Butterflies as Model Systems, 2003: p. 281-318.

119. Almen MS, et al. Adaptive radiation of Darwin's finches revisited using whole genome sequencing. BioEssays. 2016;38(1):14-20.

120. Rieseberg LH, Archer MA, Wayne RK. Transgressive segregation, adaptation and speciation. Heredity. 1999;83(4):363-72.

121. Schumer M, Rosenthal GG, Andolfatto P. How common is homoploid hybrid speciation? Evolution. 2014;68(6):1553-60.

122. Hermansen JS, et al. Hybrid speciation in sparrows I: phenotypic intermediacy, genetic admixture and barriers to gene flow. Mol Ecol. 2011; 20(18):3812-22

123. Brelsford A, Mila B, Irwin DE. Hybrid origin of Audubon's warbler. Mol Ecol. 2011;20(11):2380-9.

124. Nietlisbach P, et al. Hybrid ancestry of an island subspecies of Galapagos mockingbird explains discordant gene trees. Mol Phylogenet Evol. 2013; 69(3):581-92.

125. Lavretsky $P$, et al. Genetic admixture supports an ancient hybrid origin of the endangered Hawaiian duck. J Evol Biol. 2015;28(5):1005-15.

126. Grant PR, Grant BR. The secondary contact phase of allopatric speciation in Darwin's finches. Proc Natl Acad Sci U S A. 2009;106(48):20141-8.

127. Elgvin TO, et al. The genomic mosaicism of hybrid speciation. Sci Adv. 2017; 3(6):e1602996.

128. del Hoyo, J. and A. Elliott, Handbook of the birds of the world. 1992, Barcelona: Lynx.

\section{Submit your next manuscript to BioMed Central and we will help you at every step:}

- We accept pre-submission inquiries

- Our selector tool helps you to find the most relevant journal

- We provide round the clock customer support

- Convenient online submission

- Thorough peer review

- Inclusion in PubMed and all major indexing services

- Maximum visibility for your research

Submit your manuscript at www.biomedcentral.com/submit
Biomed Central 